Shareholder Voting Power and
Ownership Control of Companies

Dennis Leech

No 564

WARWICK ECONOMIC RESEARCH PAPERS

DEPARTMENT OF ECONOMICS 


\title{
Shareholder Voting Power and Ownership Control of
}

\section{Companies}

by

\section{Dennis Leech*}

April 2002

Forthcoming in Homo Oeconomicus

\begin{abstract}
*The ideas and results in this paper have been presented in different forms at the conferences of the European Association for Research in Industrial Economics in Turin, September 1999, "Ownership and Economic Performance", Oslo May 2000 and the Game Theory Society, Games 2000, Bilbao, July 2000, and to staff seminars at City, Oxford, Oslo, Warwick and Cambridge Universities. I am grateful to many people for comments that have led to improvements in the paper but especially the editor, and two anonymous referess. Responsibility for the final version is mine alone however.
\end{abstract}

Dennis Leech,

Department of Economics,

University of Warwick,

Coventry, CV4 7AL, UK

Email: d.leech@warwick.ac.uk

www.warwick.ac.uk/fac/soc/Economics/leech

Tel: (+44)(0)2476523047 


\section{$\underline{\text { Abstract }}$}

The pattern of ownership and control of British industry is unusual compared with most other countries in that ownership is relatively dispersed. Typically the largest shareholder in any large listed company is likely to own a voting minority of the shares. Majority ownership by a single shareholder is unusual. It is not uncommon for the largest shareholding to be under 20 percent and in many cases it is much less than that. A broadly similar pattern is observed in the USA.

Two inferences about corporate governance are conventionally drawn from this, following the early work of Berle and Means: (1) All but the very largest shareholders are typically too small to have any real incentive to participate in decision making; (2) All but the very largest shareholdings are too small to have any real voting power. The question of voting power is the focus of this paper. Conventional analyses use a rule of thumb of $20 \%$, assuming shareholders to be fundamentally passive in relation to the running of the company, whatever their style of investment management, unless one of them is above this figure. The London Stock Exchange defines a controlling holding to be one greater than 30 percent. Much empirical work uses declarable stakes, which in the UK are those of 3 percent or more, and disregards anything smaller assuming it to be powerless. In fact, however, a $1 \%$ stake in the $100^{\text {th }}$ largest company (Smiths Industries) is worth about $£ 29$ million, which suggests its owner has strong incentives to be active, and might wish to use his voting power.

Theoretical voting power of minority shareholding blocks is studied using the gametheoretic idea of voting power indices. This is applied to a model of ownership control based on the definition of control used by Berle and Means in their classic study. The results give support for use of a 20 percent rule in many cases but not all. Also they support the idea that many companies are potentially controlled by a block of a few large shareholders working in concert. 


\section{$\underline{1 . \text { Introduction }}$}

In countries such as the UK and USA, where the ownership of industry is widely dispersed among a large number of shareholders, with few companies having a majority shareholder, shareholder power is a matter of academic debate. The literature that discusses their role in corporate governance tends to divide sharply between two extremes represented, on one side, mainly by academic economists (for example Shleifer and Vishny (1997)), who emphasise the effect of ownership dispersion on the incentives of managers. These writers sidestep all questions surrounding the fundamental nature and direction of the firm, disallowing any role for ownership in control. Their view of the firm is of a kind of machine for making profits, the important question being whether its managers choose to make more or less; all decisions are more or less clear cut and corporate governance is a matter of getting the incentives right. On the other side is a smaller, less theoretical literature, deriving largely from business schools and independent corporate governance consultants, that stresses voting by shareholders and the influence deriving from it. Writers in this tradition tend to regard a firm, specifically one listed on the stock exchange whose shares are openly traded, as a public institution more broadly defined and therefore corporate governance deals with a greater range of concerns than those cast in narrowly economic terms.

The dominant view on shareholder power among the first group, which derives from Berle and Means (1932), is that because of ownership dispersion, shareholders as a group are powerless because no individual among them could be said to have any appreciable voting power or control. Using ownership dispersion as a paradigm, they have emphasised the moral hazard argument that in general even a relatively large 
shareholder has little incentive to monitor the performance of the management, to take an interest in the direction of the firm or even to vote their shares because their ownership stake - small in percentage terms - gives them only a small entitlement to the returns accruing to their investment in those activities. The second group tends to advocate better standards of corporate governance through greater shareholder involvement. They base their position on the power of the vote as a fundamental part of equity ownership and have a different paradigm: that of a world of large institutional investors whose power and influence derives from managing huge pension and insurance funds. A firm is often faced with fundamental uncertainty about its nature and direction so that strategic decisions must be taken in the absence of full information. Shareholders have the central responsibility for all this; there is considerably more to their role than simply designing mechanisms to motivate managers to maximise the value of the firm. The role of shareholders is to determine all questions that are not routine, that cannot be decided by management because they are relevant to the relationship between the company and the capital market, and these include all fundamental matters affecting it.

This paper is a contribution to the literature on the latter question. I abstract from the question of incentives here and concentrate solely on voting power. I also apply this to study the idea of minority control first proposed by Berle and Means. For present purposes I maintain the assumption that shareholders always do have incentives to take part in monitoring the management and voting their shares. This is obviously an unreal assumption because it is not worthwhile for very small shareholders with holdings of only a few thousand pounds to be active owners, but it biases the analysis away from finding shareholders to be powerful. Therefore the results of the analysis are stronger to 
the extent they point to evidence of shareholders as being powerful. If the analysis is confined to larger shareholders who have incentives to be active deriving from the size of their holding, then it is likely to find some of them to be very powerful. However that depends on having a model of shareholder incentives and is left to another study. (See Leech (2002b) for an analysis of investors' incentives to corporate governance activism.) I am here exclusively concerned with the important conceptual and statistical issue of the relation between the size of an ownership stake and the power or control it represents.

\section{Corporate Governance and Shareholders}

That the term corporate governance has come to be used for the system by which firms are regulated is a testimony to shareholder power in both the United States and the United Kingdom. Corporate governance became a policy focus in the United States earlier as a result of the growth of financial institutions especially public sector pension funds who found themselves to be relatively important shareholders and saw that they had a direct interest in being active as owners. In the 1980s they became concerned to protect their rights as owners against attempts by the top management of many companies to introduce anti-takeover measures and effectively limit their accountability to shareholders. Their resulting campaign preserve and strengthen shareholder democracy was successful and they later moved on to using their voting power as a weapon to improve performance. Some financial institutions, for example CalPers, the California Public Employees pension scheme, explicitly adopted a policy of engagement with management of underperforming companies, threatening to use their voting power to force changes in the board and replace the chief executive if performance targets were not met. A factor that contributed to this change of approach - 
institutional shareholders had previously restricted themselves to a role as active managers of a portfolio, reacting to underperformance by a company by selling its shares - was the large size of some of the holdings which made it difficult to sell without damaging the market. Also many of them held essentially passive portfolios. Thus the policy developed, articulated by CalPers, was one of "active ownership combined with passive investment" "1 which depended on good standards of corporate governance in terms of the relationships between firms and shareholders.

The corporate governance movement in the UK originated differently and somewhat later. In the early eighties a number of rather high profile corporate failures (Maxwell, Polly Peck, BCCI) that were due to mismanagement or wrongdoing by management showed fundamental inadequacies in the system of corporate governance. Investors themselves rather than the government decided that it was necessary to act and so the response was to introduce a voluntary code of practice, rather than government legislation, to ensure high standards of behaviour. The fundamental principle behind this approach was shareholder power based on greater disclosure of information and also structural changes in the way boards are run leading to greater accountability of management, and shareholders being expected to discharge responsibilities as owners by actively engaging with management and voting their shares. The Cadbury Code, recommended a number of changes in the way boards operate, such as the separation of the roles of chair and chief executive, non-executive directors, remuneration committees, nomination committees, as well as shareholder voting, and it has now become a standard expectation that firms comply. The thinking behind it is very much

\footnotetext{
${ }^{1}$ Investment is passive because based on a buy-and-hold strategy; ownership is active because of direct engagement with managers. See Nesbitt (1994).
} 
in terms of standards of public conduct, for example non-executive directors have a key role because of their independence. The code has now become standard practice and it is a requirement for listing that companies provide a statement of their policies in relation to it.

From the point of view of shareholder accountability companies can be seen as public bodies and their governance discussed in the same way as that of government bodies. Corporate governance then becomes a matter of standards of behaviour, probity and accountability ${ }^{2}$. Firms are expected to comply with a code of conduct in order to protect shareholders and to create the information and the conditions to enable them to act as rational economic agents in their dealings with the firm. Shareholders are the group to whom the management is accountable and voting is the mechanism by which it is enforced. Shareholder democracy is similar to political democracy in that decisions that must be taken are in the nature of public goods. If an individual shareholder makes a proposal that ensures the firm is well run and profitable the benefits accrue to all shareholders in proportion to their shares, and the individual cannot gain disproportionate personal advantage. Shareholders are not in conflict with each other about the division of the profits; that is fixed by the distribution of shares and the openness surrounding a public company. At the heart of the system of corporate governance is the private provision of a public good. An analysis of shareholder incentives along these lines is presented in Leech (2002b).

Traditionally the role of shareholders has been discussed in terms of control of the company, and this paper is no exception because control involves a level of power that is easy to understand. However, many institutional shareholders do not seek control for 
a variety of reasons ${ }^{3}$. A controlling shareholding in a large company would often be larger than the rules of risk diversification would suggest, but it would also involve the investor taking a degree of responsibility for the firm which he may be ill prepared for or not want. There is also a likelihood of the investor gaining information which would compromise his share trading activities and run the risk his being accused of the criminal offence of insider trading. Most institutional shareholders are also averse to being publicly associated with a company by being seen to have control. It is therefore much more likely to be the case that shareholders seek power in the form of influence rather than control. Given the community of interests between shareholders in a company however, the question of collective control by a group of shareholders is important to determining ownership control. Voting is a matter of the shareholders deciding between management recommendations and any counter-recommendations that may be made by owners.

\section{Shareholder Voting Power and Corporate Control}

Berle and Means (1932) were the first to study in detail the links between the concentration of share ownership, shareholder voting power and company control. They showed that in 1929 ownership of a typical large corporation in the United States had become widely dispersed among a very large group of small shareholders. The most important shareholdings of many large corporations were found to be very small indeed - in percentage terms - often less than 1 percent of the voting stock. Berle and Means inferred that in such cases no shareholding could be sufficiently powerful to be able to exert any real influence with management and that therefore such corporations could

\footnotetext{
${ }^{2}$ It is in these terms that the matter is discussed in the Cadbury Report (1992).

${ }^{3}$ As reported for example in Charkham and Simpson (1999).
} 
not meaningfully be considered to be controlled by their owners. In the default of ownership control they were assumed to be management controlled. It should be noted in passing however that their analysis was in terms of shareholdings in percentage terms and in large corporations even quite small percentage holdings represented very substantial accumulations of wealth.

Not all public companies had such dispersed ownership however. A few had a majority controlling shareholder, often the founder, or another corporation. More common was the situation where there was a large minority shareholder; in many cases such a shareholder was found from other evidence to be able to dominate through his voting power, and in effect had control. Others were controlled by minority ownership blocks through a legal device such as pyramiding or dual class shares, rather than the voting power deriving from a large minority holding.

Berle and Means made numerous detailed case studies to establish the relationship between ownership structure and control. They examined both cases where there was a stable control regime in which a corporation had obviously been controlled by the same minority shareholder or group over a long period, and also cases where there had been a proxy fight and control had either changed hands or been reaffirmed in a proxy fight. The evidence they used was a careful reading of press reports and also the kind of detailed analyses available to investors in brokers' notes and so on, so called "Street knowledge" (i.e. Wall Street knowledge). They were particularly interested in determining the point at which a minority shareholding became so small that it was no longer able to dominate voting. They identified "working control" if a minority shareholder had "sufficient stock interest to be in a position to dominate a corporation through their stock interest" and "...the ability to attract from scattered owners proxies 
sufficient when combined with their substantial minority interest to control a majority of the votes at the annual elections [of directors]. Conversely this means that no other stockholding is sufficiently large to act as a nucleus around which to gather a majority of the votes."

Berle and Means' careful use of case study evidence, rather than for example a simplistic statistical analysis of voting figures at annual meetings, is particularly appropriate since they were interested in studying power, and power by its nature is often difficult or even impossible to observe directly. For example, the existence of control by a shareholder would never be revealed to an investigator if it were never formally challenged by proxy vote or vote at company meetings. The exercise of power might be real nevertheless, with decisions being taken by the controlling shareholder and communicated to management through informal channels. It would be just as real in the circumstance, even more difficult to observe but easy to imagine, where the management understood the controlling shareholder so well that there were no need for even informal communication, perhaps because they had worked together for so long that they were of one mind. Moreover this would be well known to all the major investors in the company, even if not immediately obvious to an outsider.

The methodological question of how to study power in general has been discussed at length by Morriss (1987). He argues that intrinsically power can rarely be observed directly and that any evidence must be used in indirect ways: "there is no easy mechanical way of establishing how much power someone has and the connection between the assertion that someone has power and the evidence for it is often complex and subtle." Consequently he argues that power should best be studied using a variety of approaches within a regime of "methodological tolerance". Specifically he maintains 
that research into power should not be confined to the use of "hard" evidence. His most radical proposal is that researchers should be allowed to use information gained by asking other people whose opinions might be taken as authoritative evidence: by their background or practical experience they are experts.

Morriss suggests that there are five general approaches to gaining evidence about power that should be used in conjunction with each other: (1) Experiments; (2) Thought experiments; (3) Natural experiments; (4) Consulting experts; (5) Resource-based approaches. The approach adopted by Berle and Means fitted into this framework, and can be thought of as a combination of (3), (4) and (5). Direct experiments were impossible. Thought experiments apply to situations where the conclusion can be worked out theoretically, for example a control structure based on a legal device is obviously different from one based on a powerful minority voting block. Berle and Means' basic data were provided by natural experiments, the usual case in empirical economics.

Resource-based approaches study power in terms of the basic resources from which it derives; in the context of ownership control the relevant resources are the shares of different shareholders, in the context of the voting rules defined in the Articles of Association, and Berle and Means' attempts to define and identify controlling shareholdings comes into this category. The manner of the distribution of the shares among different shareholders determines the power of each particularly the largest shareholder. A large minority shareholder has control if the remaining shares are so widely distributed among a mass of small shareholders that it is very likely to be able to determine the outcome of a vote. In general the votes of the small shareholders are likely cancel each other out and give the power of decision to the large blockholder. 
However, where the second largest shareholder has a large weight, this power is denied to the largest shareholder and he does not have working control. Likewise if there are a number of substantial blockholders. The analysis of control depends on the complete distribution of ownership among all shareholders (and the decision rule, which for firms is almost always a simple majority). Studying this relationship formally is the primary purpose of this paper.

Berle and Means in effect made a lot of use of Morriss' approach of consulting experts by relying on newspaper reports and "Street knowledge" to obtain independent evidence on control and related this to their shareholding data. They did not infer that a corporation was owner controlled unless they were sure they could observe it, even if indirectly, in their case studies. They reached the conclusion that a shareholding was sufficiently large to have working control through voting power if it was larger than about 20 percent, although this could vary, in many cases the figure being rather lower or higher depending on the other shareholdings. The use of this 20 percent rule to define a shareholding as controlling is commonplace in empirical work, most recently by La Porta et al. (1999).

More recent indirect evidence on the relationship between shareholder voting and control of the "consulting experts" type is in the listing rules of the London Stock Exchange (the "Yellow Book" , London Stock Exchange(1993)) which uses the term controlling shareholder for one which determines the votes of 30 percent or more of the shares of the company. This official definition has been drawn up by the members of the exchange in the light of their combined wisdom and experience, as practitioners who regularly back their judgement with both their own wealth and that of others, as well as their reputations. It might be supposed therefore that it has not been done lightly 
and might therefore be supposed to be a reflection of the opinion of experts. It is significant that it is in terms of a minority holding with working control well under the 50 percent needed for legal control.

\section{The Measurement of Voting Power}

Since different shareholders cast different numbers of votes according to the sizes of their holdings the analysis of voting power and control is a natural application of a weighted majority voting game. These games are interesting because a key property of weighted voting is that the power of each player, as the ability to influence the outcome of any particular vote, does not have a simple relation to that player's voting weight. Formally it is necessary to distinguish between voting weight, represented by the shareholding, and voting power, as the ability to swing a vote, that is, the ability to swing a coalition of players from losing to winning by joining it.

An example illustrating this point is a company with three shareholders whose holdings are 49, 49 and 2 percent. Clearly although the weights differ considerably, one of the shareholdings being very much smaller than the others, when we consider their individual power to swing the decision, they are all equal. Any two are required for a simple majority decision: the 2 percent player can join with one other to swing the vote from a minority with 49 percent to a majority with 51 percent $^{4}$, and each of the two 49 percent players can swing the vote from 49 percent to a majority with 98 percent.

Counting the number of swings each player can make gives an absolute measure of power. Taking into account also the total potential number of votes which can be

\footnotetext{
${ }^{4}$ The decision rule requires a 51 percent majority here because the examples involve discrete data. The analysis of the real data later in the paper will use a 50 percent rule.
} 
taken within the game, or the potential total number of swings among all the players, enables a power index to be defined for each player. Consider first all the four possible coalitions of votes which the 2 percent player could join: $\{\varnothing\}$ (the empty set), $\{49\}$, $\{49\},(49,49\}$, the total votes being $0,49,49,98$ which would become $2,51,51$ and 100. It can therefore swing two of them, the two with 49percent; it can make no difference to the decision by voting with the coalition in the other two cases. This player can therefore swing $1 / 2$ of the decisions so its power index is $1 / 2$. For one of the 49percent players, the coalitions are $\{\varnothing\},\{2\},\{49\},\{2,49\}$ and the total numbers of votes are $0,2,49,51$ which become 49, 51, 98, 100. Therefore this player with 49 percent weight can swing two decisions out of 4 and therefore its index is also 1/2. Therefore each of the three players has an ability to swing $1 / 2$. It is mathematically convenient to consider all the possible voting outcomes which could occur as if they were random and equally likely since the approach treated each equally. Therefore the probability of a swing is $1 / 2$ for each player. $^{5}$

By contrast, as an example which illustrates the utility of the approach, consider a company with one shareholding of 30 percent and 70 shareholdings of 1 percent. A decision by majority vote requires 51 percent support. Consider the power of the large blockholder. There are $2^{70}$ different possible coalitions of the small players, since each can vote either "for the motion" or "against the motion". Assuming each small player votes each way with equal probability independently of the others, the total number of

\footnotetext{
${ }^{5}$ There are three players each with a power index of $1 / 2$. In the literature on power indices it is frequently assumed that the total power of decisions is divided among the players so that the indices represent shares of power and sum to one. In this example if such a normalised index were used each player would have an index of 1/3. I do not adopt this approach for reasons discussed below, following Coleman (1971).
} 
votes cast by them "for the motion" - call this $\mathrm{Y}$ - is distributed with a binomial distribution, with parameters (in the usual notation) $n=70$ and $p=0.5$, or in the usual shorthand, $\mathrm{Y} \sim \mathrm{B}(70,0.5)$. The swing probability of the large player is then found using this distribution, as the probability that the large player can swing the vote, which occurs when $\mathrm{Y}$ is at least 21 and less than 51 . This is the binomial probability, $\mathrm{P}(21 \leq \mathrm{Y} \leq 50)=0.999370$. Therefore the 30 percent player is very powerful, in that his swing probability is very close to unity indeed, but it is necessary to check the powers of the small players also to establish relative power.

So consider a player with 1 percent of the votes. A swing occurs when that player is able to change a losing coalition into a winning one, which means changing one with 50 percent of the votes into a 51 percent majority. In this case it is necessary to consider the total votes of 69 small players as random and also to treat the votes of the largest player as being random. The total number of votes cast by the small players, say $U$, has the binomial distribution, $\mathrm{U} \sim \mathrm{B}(69,0.5)$. To find the swing probability of a small player with 1 percent of the votes it is necessary to allow for the possible behaviour of the large player as well as the other 69 small players. There are two equally probable cases: (1) where the large player votes "for", so therefore for a swing $30+U=50$, and so we must have $\mathrm{U}=20 ;(2)$ where the large player votes "against" so therefore $\mathrm{U}=50$ for a swing. The swing probability for the small player is then $0.5 \mathrm{P}(\mathrm{U}=20)+0.5 \mathrm{P}(\mathrm{U}=50)=$ 0.000137.

It is clear from this example that the player with 30 percent is effectively totally dominant and has very close to complete control, while the small players individually are virtually powerless. This property of weighted voting to assign very great power to a block of votes faced by a very dispersed distribution among a large number of other 
players explains why shareholder power is so important to the system of corporate governance even in countries with dispersed ownership like the UK. Dispersed ownership in itself does not necessarily imply dispersed power.

The idea of a power index as a general measure of voting power originated in the classic paper by Shapley and Shubik (1954 and 1988) ${ }^{6}$. The Shapley-Shubik index proposed there was an application of the Shapley value (Shapley (1953 and 1988)) as a method of evaluating the worth to each player of participating in a game. The central idea of the Shapley value was bargaining among the players over the spoils of a decision. This bargaining approach to thinking about voting in a collectivity was however severely criticised by Coleman (1971) who argued that the consequences of a collective decision taken by majority voting could not usually be thought of in this way. A decision about an action that the collectivity could take would have consequences for the members that could only be understood in the wider context, and could not be conceived of as sharing the spoils. An example would be a decision to replace the top management in a public company: if performance subsequently improved entitlement to the additional profits would normally be distributed among all shareholders in proportion to their shareholdings and not according to their individual voting powers.

The alternative approach therefore is one in which the outcomes are in the nature of public goods; voting is a matter of political democracy and the power index is a measure of general voting power and not a value. Coleman advocated an approach in

\footnotetext{
${ }^{6}$ Shareholder voting was always suggested as an application of these ideas, right from the earliest days, see Shapley (1961).
} 
which the voting body is analysed in terms both of the powers of voting members ${ }^{7}$ and also the power of the body itself to act. Banzhaf (1965) proposed an index of power in weighed voting situations based on a different coalition model from that of Shapley and Shubik - the model that I have described above. Both these indices are often referred to in the literature as the classical power indices and both have been widely applied with sometimes similar but often widely different results. This has led to a problem of choice of index and, in the absence of independent evidence on the powers of players in the real-world weighted voting games to which they have been applied ${ }^{8}$, to something of an impasse in the development of the field. This has prompted considerable theoretical work on the comparative properties of the indices, to the proposal of new indices, and also to the rejection of the power indices approach entirely. Nevertheless the method promises to have utility in the analysis of power in general voting systems and in the design of constitutions.

Accounts of the measurement of power and of the different indices and the theoretical debates on their comparative properties are given in Lucas (1988), Straffin

\footnotetext{
${ }^{7}$ He proposed separate measures of the power to initiate action and the power to prevent action but this distinction only matters for bodies which employ a supermajority. When the decision rule requires only a simple majority for a decision these two indices are equivalent. For this reason Coleman's approach has tended to be dismissed as equivalent to that of Banzhaf and there have been few if any applications of it. Coleman argued forcefully against the idea of a power distribution in which the total power of decision making is shared out, which is a central idea in the Shapley-Shubik index. The swing probabilities used in the current paper can be thought of as Coleman's powers to initiate action but I also use normalised power indices, or Banzhaf indices, to measure, not shares of power, but relative powers of different players.

${ }^{8}$ For example the United Nations, the US Presidential Electoral College, the European Union Council, and others.
} 
(1994) and Felsenthal and Machover (1998). An empirical comparison of the two classical indices which clearly suggests the inadequacy of the Shapley-Shubik index is reported in Leech (2002a) and on the basis of that analysis this paper will confine itself to the use of the Banzhaf (non-normalised version) or Coleman index, which will be referred to below simply as a power index. The details of the calculation of the indices are omitted. They are given in Leech $(2001)^{10}$.

\section{The Applicability of Power Indices to Shareholder Voting}

The approach to the measurement of power just described treats the firm as a public body regulated by high standards of corporate governance including the legal protection of shareholder rights, rather than simply a source of profits to be split among the owners by bargaining based on power, a model perhaps more appropriate to private companies. The question arises as to whether the measure of power used is appropriate in this context given its assumptions. The power index is a measure of abstract power

\footnotetext{
${ }^{10}$ In a previous paper (Cubbin and Leech(1983 and 1999)), John Cubbin and I proposed a measure of the voting power of the largest shareholding block which we called the degree of control. The degree of control was defined as the probability that the largest block could be on the winning side in a vote, assuming the same voting model as the power index. There is a simple relation between it (denoted by DC) and the power index for the largest shareholder, $\mathrm{PI}_{1}$ $=2 \mathrm{DC}-1$.
} 
and has no regard for preferences or the issues about which voting takes place. This is obviously something that has to be qualified since it will not apply in all cases. It can not be applied to issues on which all shareholders are unanimous, such as a policy which makes them unambiguously happier or one that reduces the value of the firm with no offsetting benefits. Nor can this model be used to make statements about control involving a powerful minority shareholder being able to expropriate the majority by appropriating the private benefits of control to himself.

The approach adopted in this paper is one where the firm is regarded as a democratic body that has to make strategic decisions in situations of fundamental uncertainty where the potential for making mistakes is enormous. There are many situations where this occurs. For example, a retail company may have enjoyed considerable success in expanding its sales of a new brand and have developed a chain of very profitable shops. The chief executive may wish to build on this success by an ambitious policy of expansion on a much larger scale and proposes the purchase of a large store, much larger than any in the chain, in the centre of every major city in the country. Extrapolating past performance, the proposal would seem to be profitable, but the quantum change in scale involved raises the question of whether the formula that has been successful in the past would still continue to be so. Another example would be where a successful business expands abroad; there are many examples of British and German companies that have lost out by attempting to expand into the United States.

Other examples occur where changes in the external trading environment take place which necessitate a fundamental strategic reappraisal. An example would be a successful clothing retailer which develops its own credit card primarily for use in its stores; demand for clothes falls as the market for clothing changes with changing 
consumer tastes leaving the company with a profitable financial services division but no longer a profitable clothing seller. Shareholders will inevitably have to decide between two incommensurable strategies: on the one hand, changing the fundamental nature of the business from primarily selling clothes to financial services, and on the other, a new management plan confidently proposed which will guarantee to restore former glory. A common case is where the board of directors is split, the management on one side and the non-executive directors on the other, the shareholders having to resolve the issue.

Another example that occurred recently in the UK is where there two rival bids to take over a company, which may differ in the bid price but are also different in the method of financing. Both bids are in terms of a mixture of cash and shares but the higher bid has a higher share element and there is uncertainty about what the share value will be. In such a case the model of shareholder voting applies since there is no objective reason to vote either way in the absence of information. Another case where the model might apply is where the chief executive wishes to be paid a large rise on promises of future success; shareholders must decide this on the basis of unknowable future performance. Where there is always this kind of uncertainty is in the appointment of directors and especially the chief executive; there may be two candidates with similar track records and there may be strong reasons for appointing each, but there may turn out to be large differences in competence in the future were either to be appointed.

In all such cases, the voting model used to measure shareholder power is a reasonable approximation and also the voting power of large shareholders is important in determining the outcome. Shareholders usually have to decide whether to accept management proposals to enhance shareholder wealth which also benefit management. Often the benefit obtained by management is in the short run and that by shareholders 
over a much longer term. In the absence of substantial share ownership by management, which is a reasonable assumption since directors holdings are no longer significant in the great majority of companies in the UK, there is little difference of interest among shareholders, and therefore shareholders are not likely to be committed to any particular side in the vote.

\section{A Model of Ownership Control}

In previous work (Leech (1987)) I proposed a model of minority ownership control based on the formal voting power of the largest block of shares as measured by a power index or the degree of control. A company is classified as owner-controlled if the power index for the largest shareholder or group of shareholders exceeds some very high level and no other has any appreciable voting power. The essential advantage of this approach over the conventional "fixed rules" approach to determining control used by many authors ${ }^{11}$ is that the power of a large ownership block depends not only on its percentage of the voting equity but also on the dispersion of the other shareholdings. The fixed rule infers control only from the size of the largest block. Thus, for example, a shareholder with $20 \%$ of the shares could be regarded as controlling in some cases but not in others on the basis of power indices, while it would always be deemed to be controlling if a fixed $20 \%$ rule were used.

Figure 1 shows the model of minority voting control described in Leech (1987). The horizontal axis shows the number of members of the potential controlling group, starting with the largest and adding successively smaller holdings. Let the block

\footnotetext{
${ }^{11}$ See Short (1994) for a survey. La Porta et. al. (1999) have recently used a fixed rule based on $20 \%$.
} 
consisting of the $\mathrm{k}$ largest shareholdings comprise $\mathrm{s}_{\mathrm{k}}$ shares and its corresponding voting power be measured by its power index, $\mathrm{PI}_{\mathrm{K}}$; both functions are shown on the vertical axis. A typical concentrated ownership structure is shown with the ownershipconcentration function $\mathrm{s}_{\mathrm{k}}$ and the power-index function $\mathrm{PI}_{\mathrm{k}}$. The block has majority control when it has $\mathrm{k}^{\prime}$ members, such that $\mathrm{s}_{\mathrm{k}^{\prime}}=0.5$ and therefore $\mathrm{PI}_{\mathrm{k}^{\prime}}=1$. The block is assumed to have minority control when its power index is very close to 1 . In the diagram this is represented as being when the block size is $\mathrm{k}^{*}$ members and its voting power is $\mathrm{PI}^{*}$. The threshold $\mathrm{PI}^{*}$ is chosen appropriately. This model is the basis of the empirical approach reported in the next section ${ }^{12}$. Since the model is being used here to examine properties of the distribution of ownership, and the blocks are theoretical rather than actual, in the results section below they are referred to as "controlling" in quotes.

\section{The Data Set: Large Voting Shareholdings in a Sample of Large UK Companies}

The data set is based on the sample collected by Leech and Leahy (1991). It consists of those companies, 444 in number, where there was no majority shareholder. All were listed on the London Stock Exchange in the mid-eighties and included about a third of the Times 1000 as well as some smaller companies and some financial companies. They comprise neither a representative sample nor a random sample since they were chosen on the sole basis of the availability of detailed ownership data to give the voting weights. The source was a commercial information service, which existed for a short time, called "Who Owns What on the London Stock Exchange", to which one

\footnotetext{
${ }^{12}$ There is a potential identification problem here since the model can be used to determine control endogenously by choosing the shape of the curve $s_{\mathrm{k}}$. Therefore we might expect observed ownership structures of actual firms to reflect this.
} 
could make an annual subscription and receive periodic printouts showing details of all shareholdings greater in size than 0.25 percent of the total of each class of equity ${ }^{13}$.

For most companies there was only one class of voting share but in the small number of cases where there were two, they were combined into one distribution taking into account any differences in voting weights and voting rules. The source of the information provided by "Who Owns What on the London Stock Exchange", was company share registers maintained under the Companies Act legislation, made publicly accessible in some form at Companies House and periodically searched by the service. This provides a much richer data set than the declarable stakes of $3 \%$ or more that companies are obliged to publish in their Annual Reports (the basis of many studies of ownership and control) but requires much more processing before it is useable. Many of the holdings were in the names of nominee companies but wherever possible these were reassigned to their beneficiaries using a directory of nominees provided with the subscription to identify them. Holdings in the same firm by different members of the founding family, and other interest groups closely associated with the company, were amalgamated into a single block using surnames and other information. The data used therefore can be assumed to be reasonably close to beneficial holdings taking into account voting alliances. ${ }^{14}$

The data collected were based on searches of company registers made in 1985 and 1986. The number of large shareholdings observed (after amalgamation by Leech and

\footnotetext{
${ }^{13}$ The Warwick University Library took out a one-year subscription to it at my suggestion.

${ }^{14}$ The source and method of construction of the data set are described in Leech and Leahy (1991). There might remain a slight underestimation of the true concentration of ownership to the extent this information was incomplete.
} 
Leahy) varies in the sample between a minimum of 12 and a maximum of 56, with a median of 27. The proportions of voting equity these represent vary between 19 percent and 99 percent, the median being 66 percent. The dataset is therefore both detailed and fairly comprehensive.

The data are summarised in Table 1. The table shows the distribution of the size of the largest shareholding, $\mathrm{w}_{1}$, and also the joint distribution of $\mathrm{w}_{1}$ with the secondlargest holding, $\mathrm{w}_{2}$, in order to indicate the variation in patterns of ownership concentration between firms in the sample. Some 49 companies have relatively concentrated voting structures with $\mathrm{w}_{1}$ greater than $30 \%$, but in the great majority of cases $\mathrm{w}_{1}$ is less than 30 percent. There is also a wide range of variation in the size of $\mathrm{w}_{2}$ given $\mathrm{w}_{1}$. For example in the group of 85 companies where $\mathrm{w}_{1}$ is between $20 \%$ and $30 \%, \mathrm{w}_{2}$ is less than $10 \%$ in 38 cases, between $10 \%$ and $20 \%$ in a further 38 cases and greater than $20 \%$ in 9 cases.

Table 1 The Sample: The Largest Holding versus the Second Largest

\begin{tabular}{|c|c|c|c|c|c|c|c|c|}
\hline & & \multicolumn{7}{|c|}{$\mathrm{w}_{1}$} \\
\hline & & $<5 \%$ & $5-10 \% \$$ & $10-20 \%$ & $20-30 \%$ & $30-40 \%$ & $40-50 \%$ & Total \\
\hline & & 41 & 144 & 125 & 85 & 30 & 19 & 444 \\
\hline \multirow{6}{*}{$\mathrm{w}_{2}$} & $<5 \%$ & 41 & 46 & 15 & 12 & 2 & 2 & 118 \\
\hline & $5-10 \%$ & & 98 & 73 & 26 & 10 & 9 & 216 \\
\hline & $10-20 \%$ & & & 37 & 38 & 11 & 5 & 91 \\
\hline & $20-30 \%$ & & & & 9 & 4 & 2 & 15 \\
\hline & $30-40 \%$ & & & & & 3 & 1 & 4 \\
\hline & $40-50 \%$ & & & & & & 0 & 0 \\
\hline
\end{tabular}




\section{The Problem of Incomplete Data}

The data collected on the distribution of share ownership is necessarily incomplete because large public companies typically have many thousands of shareholders and it would be prohibitively costly to collect them all. In any case, in practice almost all of these are too small to have any real individual voting power and little would be gained by going to the trouble of collecting the data. On the other hand, however, they have a formal role to play in the voting games being assumed in this paper and therefore it is necessary to deal with them appropriately.

The solution to this incompleteness problem adopted here is to analyse two modified games for which the data we do have would be appropriate. Two sets of indices are calculated, assuming two different games where the unobserved players conform to two extremes of "concentrated" and "dispersed" ownership. These are both arithmetically consistent with the observed data. The "concentrated" case takes the extreme that the unobserved weights are all equal to the threshold for observation, $0.25 \%$ and the number of players is finite if large. The "dispersed" case assumes an "oceanic game" where the unobserved small holdings are taken to the limit where each of them is individually infinitesimally small and they are infinite in number.

Thus, for any company, say k shareholdings are observed out of a total of $n$. The shareholdings or voting weights are represented by the notation $\mathrm{w}_{1}, \mathrm{w}_{2}, \mathrm{w}_{3}$, etc. in decreasing order of size, starting with the largest, and the smallest is $\mathrm{w}_{\mathrm{k}}$ which is normally equal to 0.0025 . There is no information about the remaining $\mathrm{n}-\mathrm{k}$ holdings except that they are all no larger than $\mathrm{w}_{\mathrm{k}}$. Nor is it necessary to know n; although the

\footnotetext{
${ }^{15}$ Strictly slightly smaller.
} 
total number of shareholders could be collected from share registers, it would add very little to the analysis. The two limiting cases are referred to respectively as limiting case $\mathrm{C}$ (Concentrated) and limiting case $\mathrm{D}$ (Dispersed). For limiting case $\mathrm{C}$ it is necessary to adopt a value for $\mathrm{n}$ in the finite game. If $\mathrm{w}_{\mathrm{k}}$ is the smallest weight observed in the data, then all the non-observed weights are no greater than $\mathrm{w}_{\mathrm{k}}$. The most concentrated pattern of ownership occurs when they are all equal to $\mathrm{w}_{\mathrm{k}}$. Then the corresponding value of $\mathrm{n}$, call it $n^{\prime}$, is: $\quad n^{\prime}=\operatorname{integerpart}\left(\left(1-s_{k}\right) / w_{k}\right)+k+1$ and we let $w_{i}=w_{k}$ for all $i=k+1$, $\ldots, \mathrm{n}^{\prime}-1$ and $\mathrm{w}_{\mathrm{n}^{\prime}}=1-\mathrm{s}_{\mathrm{k}}-\left(\mathrm{n}^{\prime}-\mathrm{k}-1\right) \mathrm{w}_{\mathrm{k}}$. Obviously $\mathrm{w}_{\mathrm{k}}=0.0025$.

These two cases are analysed separately as different games, case $\mathrm{C}$ as a finite game using the algorithm described in Leech (2001) to calculate the indices and case D as an "oceanic" game. Power indices for oceanic games have been thoroughly studied and there is a good literature on them. The approach adopted here follows that of Dubey and Shapley (1979), who showed that the power indices for an oceanic game with $\mathrm{k}$ major players with combined weight of $s_{k}$ and a majority requirement or quota of $q$ are the same as for a finite game consisting only of the $\mathrm{k}$ major players and a modified quota of $\mathrm{q}-\left(1-\mathrm{s}_{\mathrm{k}}\right) / 2$. These can be calculated using the algorithm of Leech (2001). ${ }^{17}$

\footnotetext{
${ }^{17}$ Typically the finite games assumed for case $C$ have upwards of 300 players and require an algorithm which can cope with such large games. As regards the oceanic games in case D, the results of Dubey and Shapley are subject to conditions on q to ensure existence, but in this case $\mathrm{q}=0.5$ and the conditions are always met.
} 
Table 2 Power Indices for Top Shareholders, Illustrative Companies

\begin{tabular}{|c|c|c|c|c|c|c|c|}
\hline Company & Shareholder: & 1 & 2 & 3 & 5 & 10 & 20 \\
\hline \multirow[t]{3}{*}{ Plessey } & Weight & 0.019 & 0.015 & 0.013 & 0.011 & 0.009 & 0.004 \\
\hline & Index (C) & 0.254 & 0.192 & 0.165 & 0.134 & 0.112 & 0.052 \\
\hline & Index (D) & 0.361 & 0.268 & 0.230 & 0.185 & 0.154 & 0.071 \\
\hline \multirow{3}{*}{$\begin{array}{l}\text { United Spring } \\
\text { \& Steel }\end{array}$} & Weight & 0.123 & 0.109 & 0.098 & 0.037 & 0.014 & 0.005 \\
\hline & Index (C) & 0.502 & 0.433 & 0.391 & 0.117 & 0.046 & 0.016 \\
\hline & Index (D) & 0.508 & 0.440 & 0.400 & 0.113 & 0.045 & 0.016 \\
\hline \multirow[t]{3}{*}{ Suter } & Weight & 0.128 & 0.065 & 0.053 & 0.031 & 0.017 & 0.009 \\
\hline & Index (C) & 0.692 & 0.246 & 0.209 & 0.120 & 0.068 & 0.034 \\
\hline & Index (D) & 0.707 & 0.244 & 0.210 & 0.121 & 0.068 & 0.034 \\
\hline Ranks Hovis & Weight & 0.149 & 0.037 & 0.035 & 0.022 & 0.014 & 0.008 \\
\hline \multirow[t]{2}{*}{ McDougall } & Index (C) & 0.912 & 0.070 & 0.068 & 0.047 & 0.031 & 0.017 \\
\hline & Index (D) & 0.940 & 0.053 & 0.052 & 0.038 & 0.025 & 0.014 \\
\hline International & Weight & 0.163 & 0.032 & 0.018 & 0.016 & 0.011 & 0.004 \\
\hline Signal & Index (C) & 0.984 & 0.015 & 0.011 & 0.010 & 0.007 & 0.003 \\
\hline$\&$ Control & Index (D) & 0.998 & 0.002 & 0.002 & 0.002 & 0.001 & 0.001 \\
\hline \multirow[t]{3}{*}{ Sun Life } & Weight & 0.222 & 0.035 & 0.019 & 0.013 & 0.009 & 0.005 \\
\hline & Index $(C)$ & 0.9996 & 0.0004 & 0.0003 & 0.0003 & 0.0002 & 0.0001 \\
\hline & Index (D) & 1.000 & 0.000 & 0.000 & 0.000 & 0.000 & 0.000 \\
\hline \multirow[t]{3}{*}{ Liberty } & Weight & 0.2263 & 0.2257 & 0.089 & 0.050 & 0.018 & \\
\hline & Index (C) & 0.5013 & 0.4982 & 0.278 & 0.132 & 0.047 & \\
\hline & Index (D) & 0.5014 & 0.4983 & 0.280 & 0.133 & 0.047 & \\
\hline \multirow[t]{3}{*}{ Securicor } & Weight & 0.316 & 0.073 & 0.053 & 0.029 & 0.016 & 0.008 \\
\hline & Index (C) & 0.997 & 0.003 & 0.003 & 0.003 & 0.002 & 0.001 \\
\hline & Index (D) & 0.998 & 0.002 & 0.002 & 0.002 & 0.001 & 0.001 \\
\hline \multirow[t]{3}{*}{ Bulgin } & Weight & 0.310 & 0.222 & 0.045 & 0.028 & 0.009 & 0.003 \\
\hline & Index (C) & 0.862 & 0.138 & 0.122 & 0.079 & 0.025 & 0.007 \\
\hline & Index (D) & 0.874 & 0.126 & 0.120 & 0.082 & 0.025 & 0.007 \\
\hline \multirow[t]{3}{*}{ Ropner } & Weight & 0.410 & 0.060 & 0.050 & 0.020 & 0.012 & 0.003 \\
\hline & Index (C) & 1.000 & 0.000 & 0.000 & 0.000 & 0.000 & 0.000 \\
\hline & Index (D) & 1.000 & 0.000 & 0.000 & 0.000 & 0.000 & 0.000 \\
\hline \multirow[t]{3}{*}{ Steel Brothers } & Weight & 0.425 & 0.213 & 0.038 & 0.030 & 0.007 & 0.003 \\
\hline & Index $(C)$ & 0.9996 & 0.0004 & 0.0004 & 0.0004 & 0.0002 & 0.0001 \\
\hline & Index (D) & 0.9999 & 0.0001 & 0.0001 & 0.0001 & 0.0000 & 0.0000 \\
\hline \multirow{3}{*}{$\begin{array}{l}\text { Associated } \\
\text { Newspapers }\end{array}$} & Weight & 0.4995 & 0.026 & 0.021 & 0.021 & 0.013 & 0.006 \\
\hline & Index $(\mathrm{C})$ & 1.0000 & 0.000 & 0.000 & 0.000 & 0.000 & 0.000 \\
\hline & Index (D) & 1.0000 & 0.000 & 0.000 & 0.000 & 0.000 & 0.000 \\
\hline
\end{tabular}

\section{Power Indices for Illustrative Companies}

Table 2 presents power indices for large shareholdings in some illustrative companies. The firms have been selected to span the range of variation in the first two 
shareholdings within the sample. Plessey has the most dispersed ownership with a largest shareholding of under $2 \%$ and Associated Newspapers is one of several which are just short of having majority control. Two firms have been selected in each range of values for $\mathrm{w}_{1}: 10-20 \%, 20-30 \%, 30-40 \%, 40-50 \%$. In each range the two companies are those with relatively large and small values for $\mathrm{w}_{2}$. The results for these firms might then be taken as illustrative of the effects of ownership concentration in terms both of the size of the largest holding and the relative dispersion of the other holdings as reflected in the second largest. Results are shown for representative shareholders numbered 1,2, 3, 5, 10 and 20 .

The values of the power indices in Table 2 are sensitive to differences in ownership structure and vary considerably. They appear to conform to commonly held $a$ priori notions of the power of shareholding blocks of a given size in relation to others. Where ownership is widely dispersed as in the case of Plessey, power is also widely dispersed. Where it is highly concentrated, as in Ropner or Steel Brothers, with a shareholding over $40 \%$, giving control, the index reflects this. In other cases where ownership is less concentrated, there is considerable variety of results associated with differences in ownership structure.

A comparison of Sun Life and Liberty, for example, shows the sensitivity of the power of the largest shareholder to the size of the second largest shareholding. The $22 \%$ largest shareholding in Sun Life has a power index over 99\% suggesting that it can be regarded as a controlling holding and reflecting the relatively high dispersion of ownership of the other $78 \%$ of shares. In the case of Liberty, however, both the largest two holdings are above $22 \%$ which must mean that the largest shareholder is not much more powerful than the second-largest and this result is obtained; both have an index of 
about 0.5 and, in this case, the third shareholder has enhanced power as a result. A similar finding emerges for companies with a shareholding of between 30 and 40 percent. A 31\% shareholding has a power index over 99\% in Securicor where there are no other large owners. On the other hand a similar-sized stake in Bulgin has an index of only $86 \%$ because of the presence of a large second shareholder with $22 \%$ of the votes.

These results are plausible in that they are in broad agreement with both the results of Berle and Means (1932) and more recent conventional ideas about the power of shareholder blocks and minority ownership control. It has been possible to find cases where the power index for a voting block greater than 20 percent is extremely close to 100 percent.

\section{The Complete Sample}

Results for the full sample are shown in Figures 2. Figure 2(a) shows the respective power indices for the largest shareholding, $\mathrm{PI}_{1}$, against its size $\mathrm{w}_{1}$; Figure 2(b) shows the equivalent plots after the largest 4 shareholdings have been combined into a single block, of size $\mathrm{s}_{4}$. Only the results for case $\mathrm{C}$ have been presented since the oceanic indices are very close. These plots are useful for giving an insight into the respective behaviour of the power indices in the population as a whole and their potential as a basis for identifying minority control.

There is considerable variation reflecting differences in ownership structure. Concentration in terms of the size of the largest shareholding has very little effect up to over $15 \%$ but after that power varies widely. These results suggest that shareholdings between 20 and 30 percent can be said to have voting control in many cases but not in many others. Voting control is possible on the basis of a holding below 20 percent but 
such cases are not common. Most (but not all) holdings greater than 35 percent have a power index equal to or almost equal to 1 . The variation suggests that this index may be useful as a guide to control on the basis of individual shareholding data.

Figure 2(b) shows that combining the top four shareholdings into one voting block is very powerful indeed in most cases. In some companies such blocks would be majority shareholders but it is interesting that the result does not depend on this. Intuitively combining top shareholdings has a double effect in both increasing concentration via the size of the block and reducing the dispersion of the remainder; these reinforce one another in concentrating power.

\section{$\underline{\text { 11. Potential Controlling Blocks }}$}

Figure 3 examines the model of ownership control by a block of large shareholders presented above in the light of data, by graphing the power of blocks of different sizes. Results are shown for illustrative companies in which the power indices have been calculated for each assumed block of shares, of size $s_{k}$, for $k=1$ to $20^{18}$, the ownership concentration curve and the power curve. Plots are given for two companies, Plessey, which has the most dispersed ownership structure, and Birmid Qualcast, only slightly more concentrated. Each plot shows the number of members of the group, $\mathrm{k}$, on the horizontal axis and $\mathrm{s}_{\mathrm{k}}$, the size of the block, and the associated power index on the vertical axis. The plots show the same general pattern for both companies, consistent with the theoretical Figure 1, and the inference can be drawn that for the great majority of companies a block comprising a small number of top shareholders would effectively have control.

\footnotetext{
${ }^{18} 16$ for Liberty.
} 
Figure 4 investigates this effect by calculating the proportion of the sample which would satisfy the definition of control by blocks of different numbers of shareholders on different definitions of control, $\mathrm{PI}^{*}=0.99,0.999$ and 0.9999 . It shows that it is pervasive and that the power of a shareholder block comprising, say, the top six holdings would be very considerable indeed in most companies. On the control criterion of $\mathrm{PI}^{*}=0.9999$, the model would deem over 75 percent of the companies in the sample to be owner controlled. Virtually the whole sample would be owner-controlled by the top ten shareholders combined.

Figure 5 shows the size distribution of these "controlling" blocks in terms of the concentration of ownership they represent using the PI* $=0.9999$ criterion. It shows that the effect reported in the previous two paragraphs does not depend on the blocks having a voting majority. For example, continuing with blocks comprising just the top six shareholders (which are deemed to control $75 \%$ of the sample companies), in only 30 percent of companies is the block a majority, and in 22 percent of cases it is between 30 and 40 percent of the equity. On the other hand, it represents between 20 and 30 percent of the equity in only 8.1 percent of cases.

\section{Conclusions}

This paper has looked at the voting power of large shareholders in the widely dispersed ownership observed on the stock market of the United Kingdom. It has adopted a methodology due to Berle and Means (1932) supplemented by the technique of power indices for measuring power derived from game theory. The empirical findings are consistent with earlier work and also institutional practice. 
The results show that a significant minority shareholder can be very powerful, almost as powerful as a majority shareholder, if the dispersion of the rest of the holdings is sufficient. In most companies a 20 percent shareholding can have working control, but in other companies the figure is greater and in some less. In almost all companies if the top shareholders formed a voting block this would be extremely powerful. In almost all companies the top six shareholders could form a controlling voting block, whether or not it contained a majority of the shares.

The approach has treated the company as a quasi-political body in which shareholders are voters choosing public goods, a reasonable way of looking at a public company where there are good standards of corporate governance. It ignores completely the question of incentives. A better model might be one which recognises that shareholders are of two types: those with substantial stakes who have strong private incentives to take part in collective action and those whose stakes are so small that their best strategy is to abstain. This requires a model of incentives and is the subject of future work. However such a model of voting power would be likely to show that relatively small holdings are in fact very powerful within the reduced group of active shareholders that would be identified. The approach adopted here, where all shareholders are taken into account regardless of size, biases the analysis away from finding considerable shareholder power and therefore makes the the results more significant.

\section{$\underline{\text { References }}$}

Banzhaf, J. (1965), "Weighted Voting Doesn't Work: A Mathematical Analysis," Rutgers Law Review, 19, 317-343. 
Berle, A.A. and G.C. Means (1932), The Modern Corporation and Private Property, New York: Harcourt, Brace and World, Inc. Revised Edition, 1967.

Cadbury Report (1992), The Financial Aspects of Corporate Governance, London, Gee and Co. Ltd.

Charkham, J and A Simpson (1999), Fair Shares, Oxford University Press.

Coleman, J. S. (1971), "Control of Collectivities and the Power of a Collectivity to Act," in Lieberman, ed., Social Choice, Gorden and Breach, 277-287; reprinted in J.S.Coleman (1986), Individual Interests and Collective Actions, Cambridge University Press.

Cubbin, J. and Leech, D. (1983 and 1999), "The Effect of Shareholding Dispersion on the Degree of Control in British Companies: Theory and Measurement", Economic Journal, 93 (June), 351-369, reprinted in K. Keasey, S. Thompson and M. Wright (eds) (1999) Corporate Governance, Edward Elgar: Critical Writings in Economics 2, 61-80.

Dubey, P. and L. S. Shapley (1979 ), "Mathematical Properties of the Banzhaf Power Index," Mathematics of Operations Research, 4, 99-131.

Felsenthal, D. S. and M. Machover (1998), The Measurement of Voting Power, Edward Elgar.

Gambarelli, G. (1994), "Power Indices for Political and Financial Decision Making: A Review," Annals of Operational Research, 51, 165-173.

La Porta, R., Florencio Lopez-de-Silanes, Andrei Shleifer and R.W. Vishny, (1999) "Corporate Ownership around the World," Journal of Finance, 32, 1131-50.

Leech, D. (1987) "Ownership Concentration and the Theory of the Firm: a SimpleGame-Theoretic Approach," Journal of Industrial Economics. 35, 225-240.

Leech, D. (1988), "The Relationship between Shareholding Concentration and Shareholder Voting Power in British Companies: a Study of the Application of Power Indices for Simple Games," Management Science, 34, 509-527.

Leech, D (2001), “Computing Power Indices for Large Weighted Voting Games," Warwick Economic Research Paper Number 579, revised July 2001.

Leech, D. (2002a), "An Empirical Comparison of the Performance of Classical Power Indices," Political Studies, 50, 1-22.

Leech, D (2002b), "Incentives to Corporate Governance Activism”, Warwick Economic Research Papers, number 632, March 2002.

Leech, D. and J. Leahy (1991), "Ownership Structure, Control Type Classifications and the Performance of Large British Companies," Economic Journal,101,1418-37. 
London Stock Exchange (1993), The Listing Rules, (The Yellow Book), London, The Stock Exchange.

Lucas, W F (1983), "Measuring Power in Weighted Voting Systems," in S Brams, W Lucas and P Straffin (eds.), Political and Related Models, Springer.

Morriss, P. (1987), Power: A Philosophical Analysis, Manchester University Press, Manchester, UK.

Nesbitt, S.L. (1994), "Long-Term Rewards from Shareholder Activism: A Study of the CalPers Effect”, Journal of Applied Corporate Finance, 19, 75-80.

OECD (1998), Corporate Governance, A Report to the OECD by the Business Sector Advisory Group on Corporate Governance, April.

Pohjola, M (1988), "Concentration of Shareholder Voting Power in Finnish Industrial Companies," Scandinavian Journal of Economics, 90, 245-53.

Rapaport, A. (1998), Decision Theory and Decision Behaviour, $2^{\text {nd }}$ ed.,Macmillan.

Rydqvist, K. (1986), The Pricing of Shares with Different Voting Power and the Theory of Oceanic Games, Economic Research Institute, Stockholm School of Economics.

Shapley, L. S. (1953 and 1988) "A Value for n-Person Games" in Contributions to the Theory of Games, vol. II, H.W Kuhn and A.W.Tucker, eds., Annals of Mathematics Studies, 28, Princeton University Press, Princeton , New Jersey, pp 307-17; reprinted in A E. Roth, The Shapley Value, 1988, Cambridge University Press.

(1961) Values of Large Games III: A Corporation with Two Large Stockholders, RM-2650, Th Rand Corporation, Santa Monica, California (included in J.S.Milnor and L.S.Shapley (1978), "Values of Large Games II: Oceanic Games", Mathematics of Operations Research, 3, 1978, 290-307.)

Shapley, L. S. and M. Shubik (1954 and 1988), "A method for evaluating the distribution of power in a committee system," American Political Science Review, 48, 787-792; reprinted in A E. Roth, The Shapley Value, 1988, Cambridge University Press.

Shleifer, A. and Vishny, R.W. (1997), "A Survey of Corporate Governance", Journal of Finance, 52, 737-783.

Short, H. (1994), "Ownership, Control, Financial Structure and the Performance of Firms", Journal of Economic Surveys, 8, 203-49.

Straffin, Philip D. (1994), "Power and Stability in Politics," in R.J.Aumann and S.J.Hart (ed.), Handbook of Game Theory (Vol. 2), Elsevier, pp. 1128-1151. 


\section{Appendix: 1 Proof that the power curve is concave.}

To show this, consider a block consisting of the largest $\mathrm{k}$ shareholders with

combined shareholding $\mathrm{s}_{\mathrm{k}}=\sum_{i=1}^{k} \mathrm{w}_{\mathrm{i}}$. The power index for the block is $\mathrm{PI}_{\mathrm{k}}$ defined as the swing probability for the coalition $\mathrm{k}$ in the voting model in which the votes of shareholders $\mathrm{k}+1, \mathrm{k}+2, \ldots, \mathrm{n}$ are treated randomly as defined. Let $\mathrm{x}_{\mathrm{i}}$ be the number of votes cast by shareholder $\mathrm{i}$. Then $\mathrm{x}_{\mathrm{i}}$ has the probability distribution,

$$
\operatorname{Pr}\left(\mathrm{x}_{\mathrm{i}}=\mathrm{w}_{\mathrm{i}}\right)=\operatorname{Pr}\left[\mathrm{x}_{\mathrm{i}}=0\right]=1 / 2 \text {, independently for all } \mathrm{i} \text {. }
$$

Define the random variable $\mathrm{Y}=\sum_{\mathrm{i}=\mathrm{k}+2}^{\mathrm{n}} \mathrm{x}_{\mathrm{i}}$. The swing probability $\mathrm{PI}_{\mathrm{k}}$ can be written:

$$
\mathrm{PI}_{\mathrm{k}}=0.5 \mathrm{P}_{\mathrm{r}}\left[0.5-\mathrm{s}_{\mathrm{k}}<\mathrm{Y}<0.5\right]+0.5 \mathrm{P}_{\mathrm{r}}\left[0.5-\mathrm{s}_{\mathrm{k}}<\mathrm{Y}+\mathrm{w}_{\mathrm{k}+1}<0.5\right]
$$

Denoting the cumulative probability distribution function for $\mathrm{Y}$ by the function $\mathrm{P}(\mathrm{Y})$, this can be written as ,

$$
\mathrm{PI}_{\mathrm{k}}=\left[\mathrm{P}(0.5)-\mathrm{P}\left(0.5-\mathrm{s}_{\mathrm{k}}\right)+\mathrm{P}\left(0.5-\mathrm{w}_{\mathrm{k}+1}\right)-\mathrm{P}\left(0.5-\mathrm{s}_{\mathrm{k}+1}\right)\right] / 2 \text {. }
$$

Now consider the index for coalition $\mathrm{k}+1$ of size $\mathrm{s}_{\mathrm{k}+1}: \mathrm{PI}_{\mathrm{k}+1}=\mathrm{P}(0.5)-\mathrm{P}\left(0.5-\mathrm{s}_{\mathrm{k}+1}\right)$

Therefore the change in the index is:

$$
\mathrm{PI}_{\mathrm{k}+1}-\mathrm{PI}_{\mathrm{k}}=\left[\mathrm{P}(0.5)-\mathrm{P}\left(0.5-\mathrm{w}_{\mathrm{k}+1}\right)+\mathrm{P}\left(0.5-\mathrm{s}_{\mathrm{k}}\right)-\mathrm{P}\left(0.5-\mathrm{s}_{\mathrm{k}+1}\right)\right] / 2 .
$$

This expression is always non-negative if $\mathrm{w}_{\mathrm{k}+1} \geq 0$. It is decreasing as $\mathrm{w}_{\mathrm{k}+1} \rightarrow 0$, since $\mathrm{P}(0.5) \rightarrow \mathrm{P}\left(0.5-\mathrm{w}_{\mathrm{k}+1}\right)$ and $\mathrm{P}\left(0.5-\mathrm{s}_{\mathrm{k}}\right) \rightarrow \mathrm{P}\left(0.5-\mathrm{s}_{\mathrm{k}+1}\right)$. Therefore the power curve is concave increasing as drawn in Figure 1. 


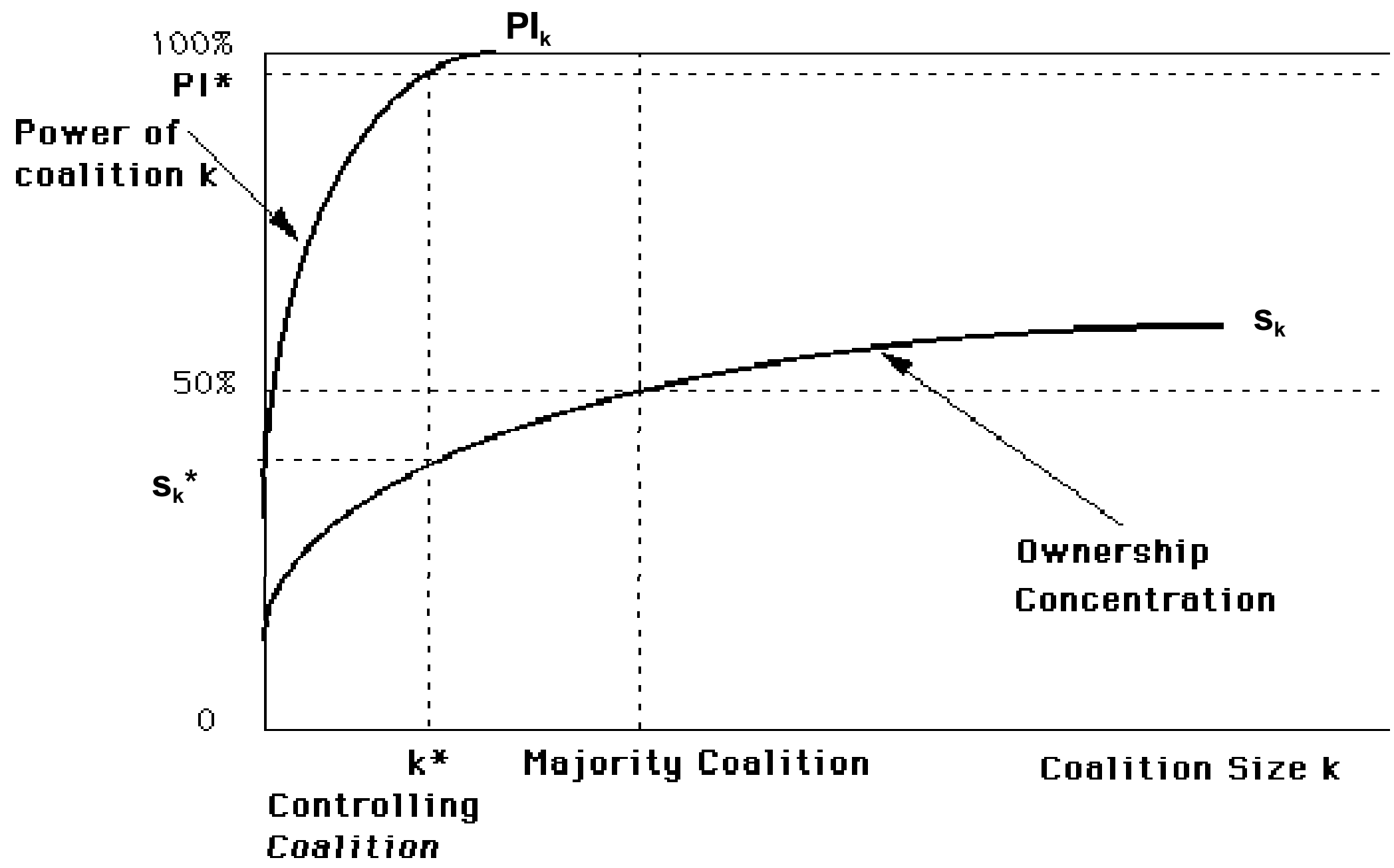


Figure 2(a)

Power Index for Shareholder 1 vs Holding Size, All Compa

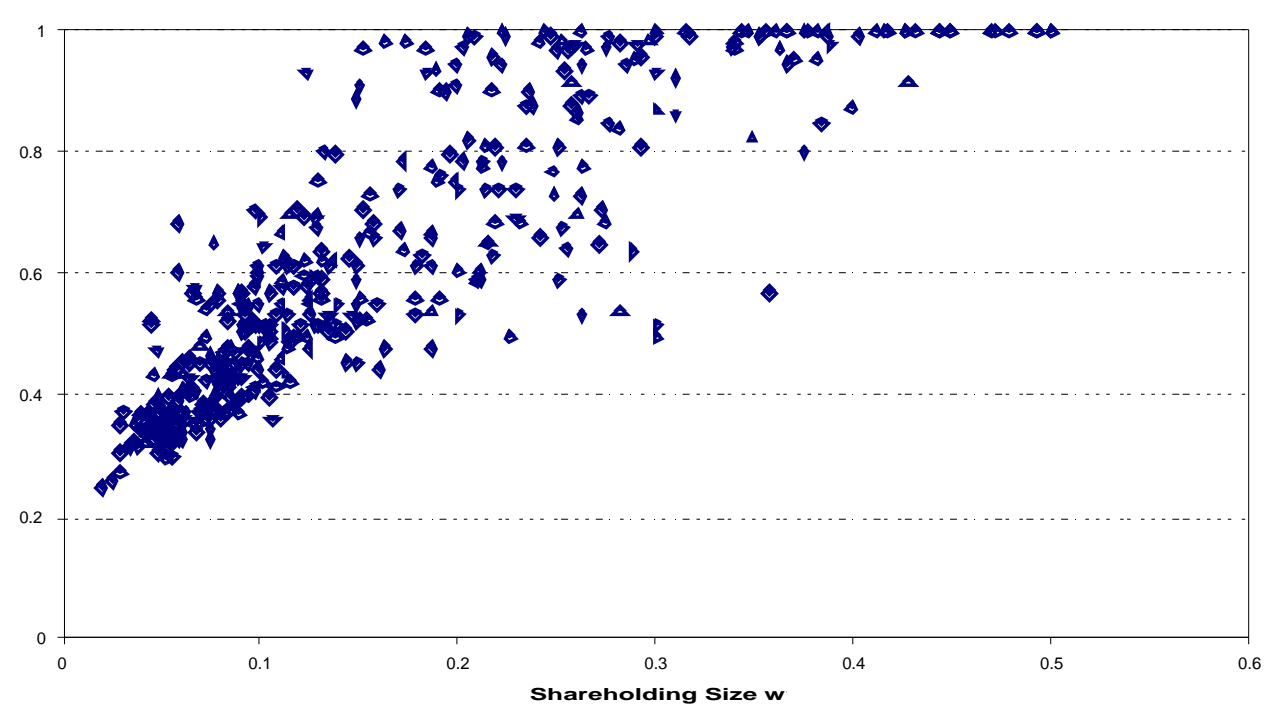




\section{Figure 2(b)}

Power Index for Block of Top 4 Holdings Combined vs Block Size, All Companies

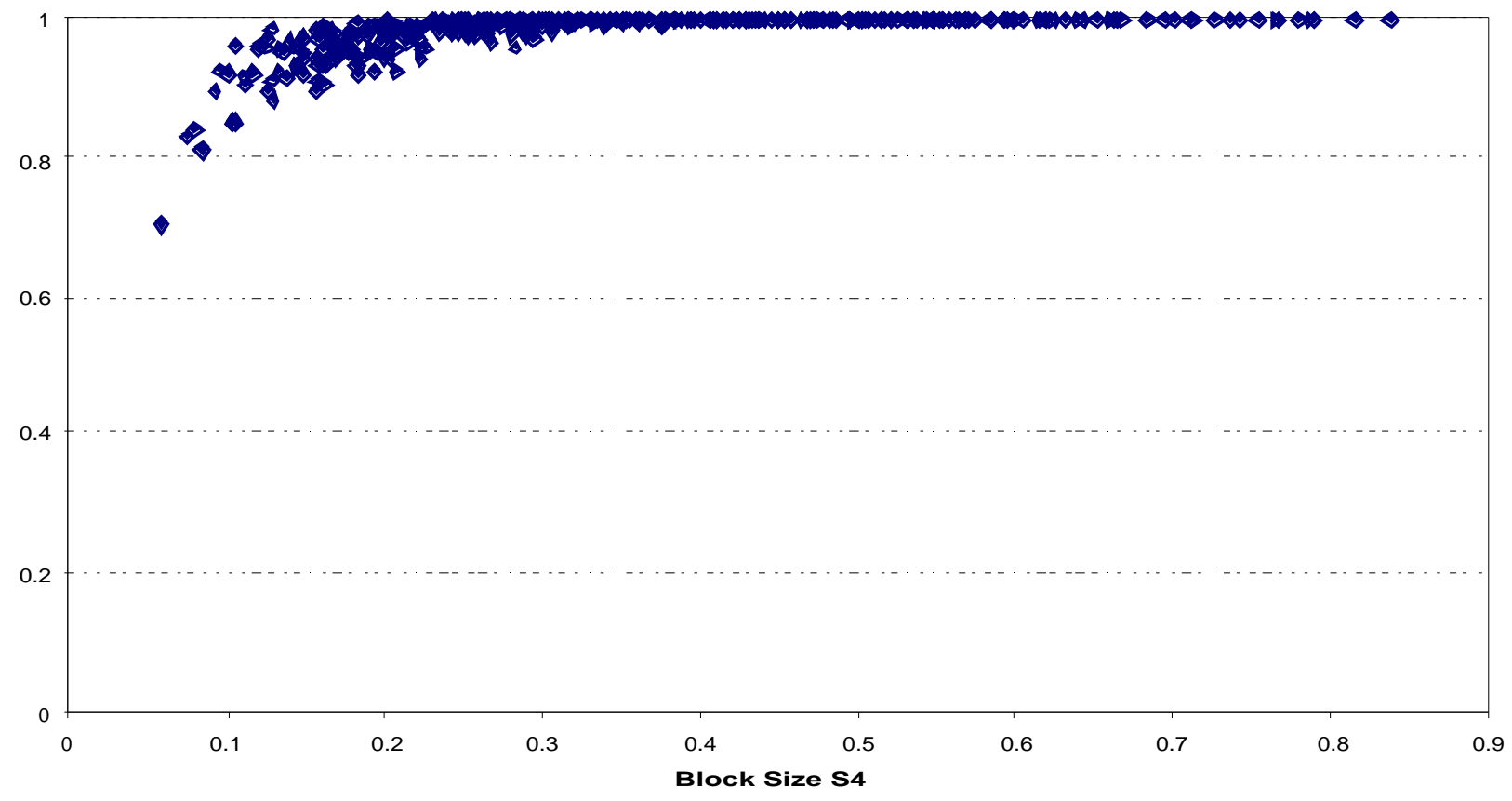


Figure 3 The Power of a Bloc of Large Shareholders

Plessey

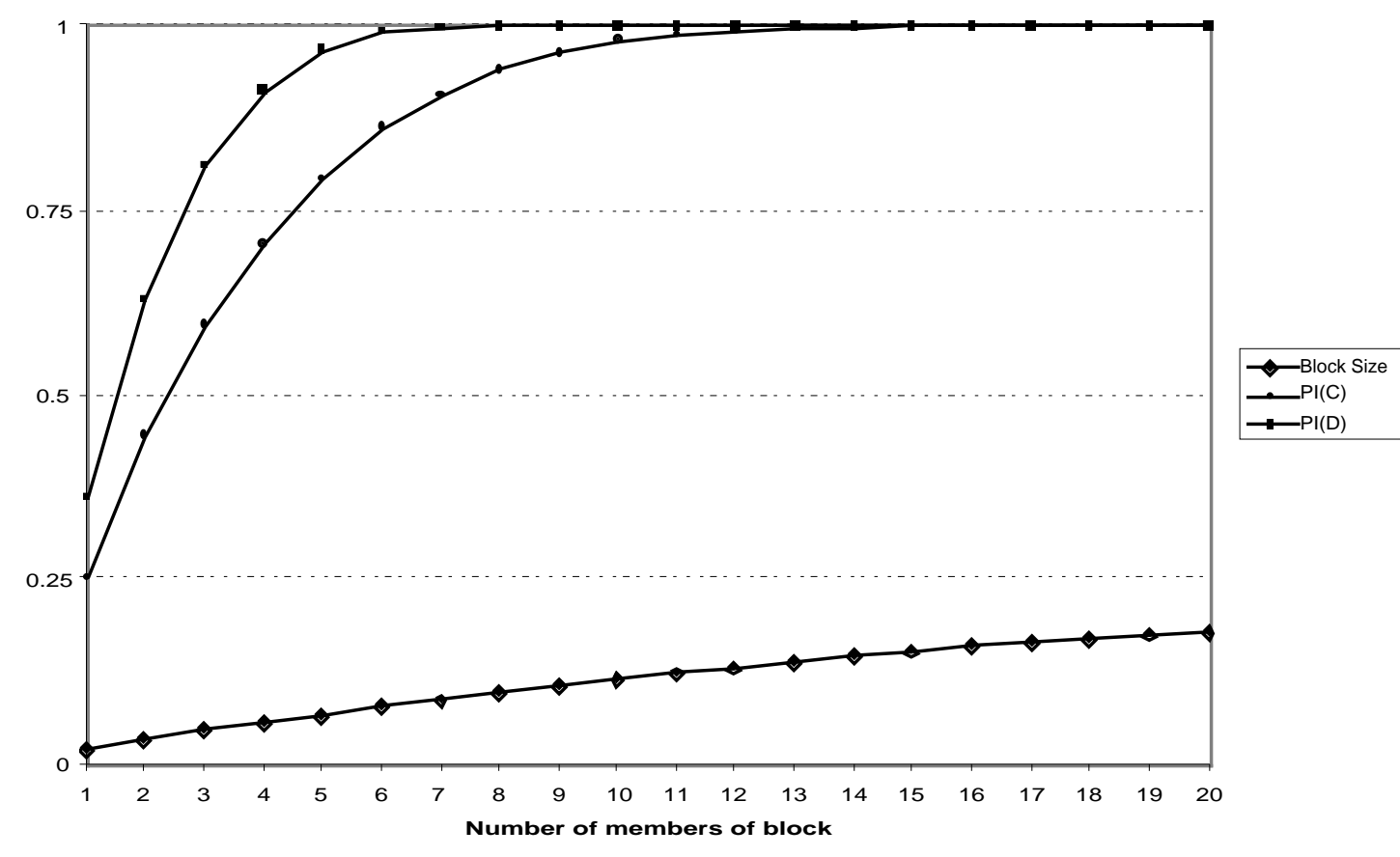




\section{Figure 4 Potential Controlling Blocs}

Percentages of Firms "Controlled" by Shareholder Blocks with Different Numbers of Members

Number of shareholders in block on horizontal axis

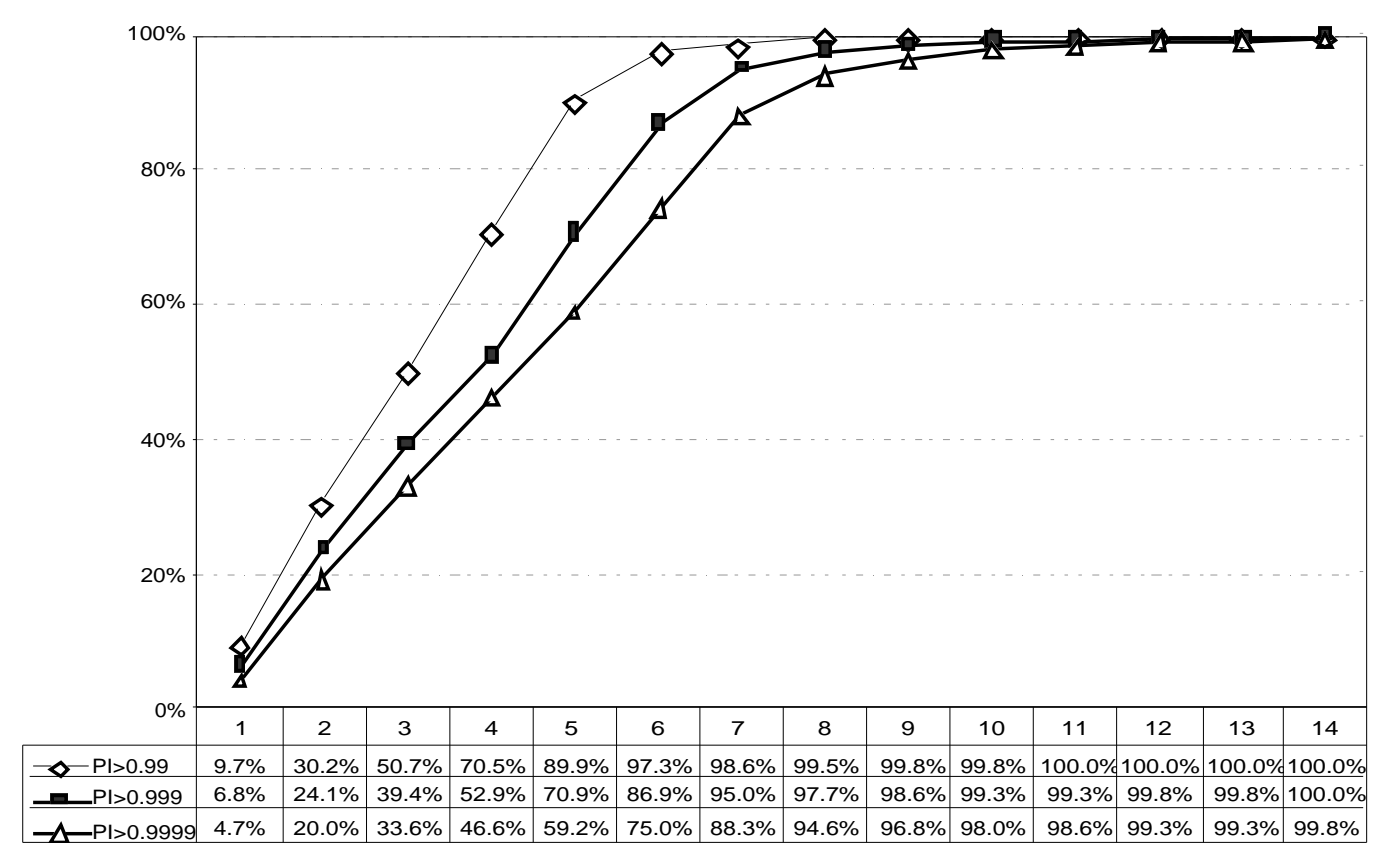


Figure 5 Sizes of Potential Controlling Blocs

Size Distributions of "Controlling" Blocks vs

Numbers of Members of Block

"Control" defined by Power Index>0.9999

Number of shareholders in block on horizontal axis

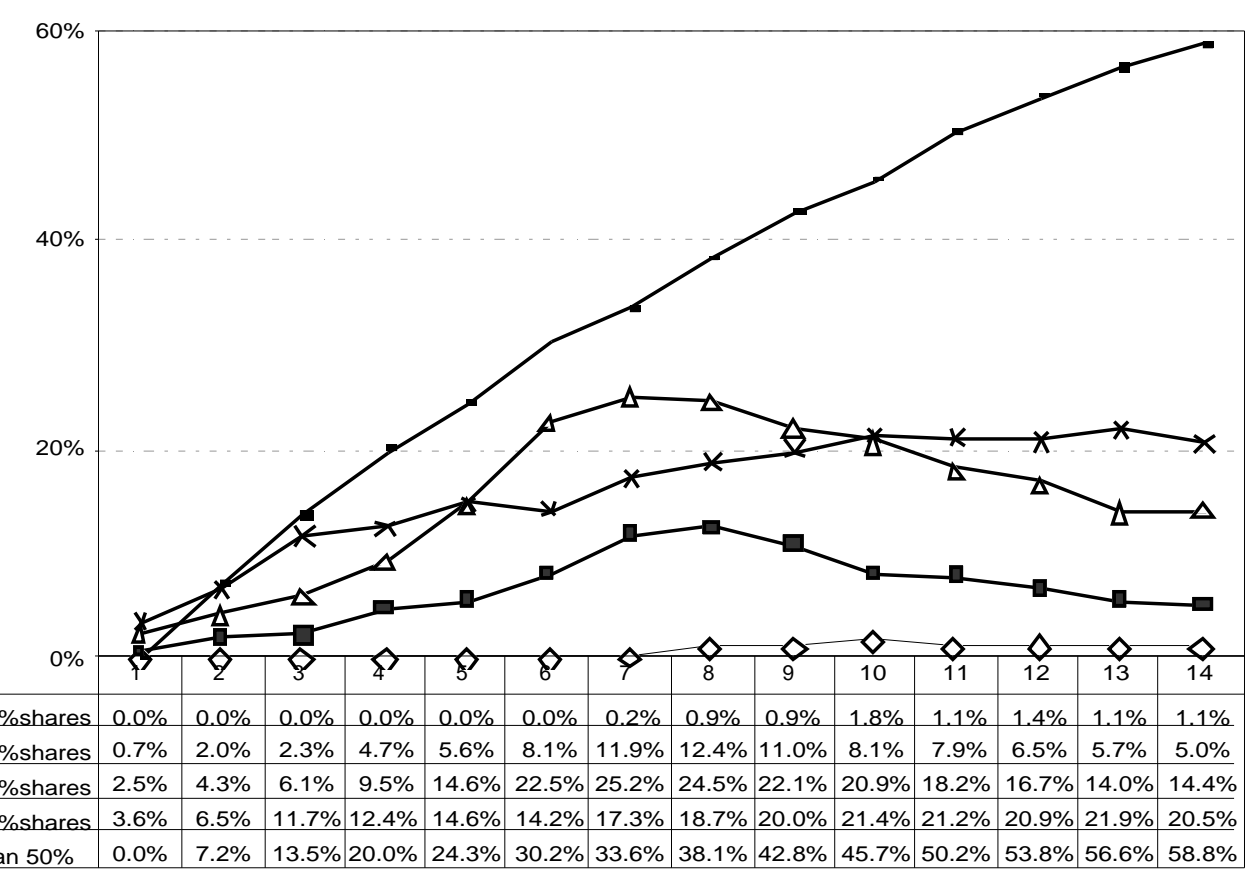

